\title{
Microbial Synthesis and Characterization \\ of Poly (3-Hydroxybutyrate-co- 4-Hydroxybutyrate) Copolymers
}

\author{
Natalia O. Zhila ${ }^{\mathrm{a}, \mathrm{b} *}$, Tatiana G. Volova ${ }^{\mathrm{a}, \mathrm{b}}$, \\ Elena D. Nikolaeva ${ }^{\mathrm{a}, \mathrm{b}}$ and Daria A. Syrvacheva ${ }^{\mathrm{b}}$ \\ ${ }^{a}$ Institute of Biophysics Siberian Branch \\ of Russian Academy of Science, \\ 50 Akademgorodok, Krasnoyarsk, 660036 Russia \\ ${ }^{b}$ Siberian Federal University, \\ 79 Svobodny av., Krasnoyarsk, 660041 Russia ${ }^{l}$
}

Received 3.06.2011, received in revised form 10.06.2011, accepted 17.06.2011

The research is focused on the prospective representative of the family of biodegradable polymers polyhydroxyalkanoates (PHAs), the copolymer poly(3-hydroxybutyrate-co-4-hydroxybutyrate) (P(3HB-co-4HB). Difficulties with producing this type of PHA are associated with the fact that the precursor for the 4-hydroxybutyrate (4HB) monomers synthesis, the $\gamma$-butyrolactone, is toxic for the bacteria producers and reduces the total biomass production and the polymer yield when it is added to the medium. Having used the natural strains of hydrogen-oxidizing bacteria Ralstonia eutropha B5786 and Cupriavidus eutrophus B10646, the latter possessing the increased sustainability to the $\gamma$-butyrolactone influence, the conditions for efficient synthesis of $P(3 H B-c o-4 H B)$ have been determined. A set of highly purified samples of $P(3 H B-c o-4 H B)$ with different content of $4 H B$ (from 8.7 to $24.3 \mathrm{~mol} \%)$ was produced. It has been determined that the incorporation of $4 H B$ in the copolymer of a higher degree than 3-hydroxyvalerate and 3-hydroxyhexanoate leads to the decrease of the copolymer's crystallinity; samples with the crystallinity of $12 \%$ and $25 \%$ have been obtained. It has been demonstrated that the average molecular weight of the $P(3 H B-c o-4 H B)$ samples and the polydispersity do not depend on the ratio of monomers and vary within the wide range from 540 to $1100 \mathrm{kDa}$ and from 1.91 to 2.76 correspondingly. It has been determined that the $4 H B$ content in the studied range (8.7-24.3 mol \%) does not effect the melting temperature of the copolymers (168.9$\left.172.5^{\circ} \mathrm{C}\right)$.

Keywords: hydrogen-oxidizing bacteria; poly(3-hydroxybutyrate-co-4-hydroxybutyrate); $\gamma$-butyrolactone; physicochemical properties.

\footnotetext{
Corresponding author E-mail address: nzhila@mail.ru
} (C) Siberian Federal University. All rights reserved 


\section{Introduction}

Synthesis of the storage polymers hydroxy derivatives of alkanoic acids polyhydroxyalkanoates (PHAs) - by microorganisms has become an extensively studied subject. PHAs are represented by various polyesters, consisting of homogenous monomers with different length of the carbon chain and by copolymers; there are high-crystallinity thermoplastic PHAs and thermolabile rubber-like elastomers (Philip et al., 2007).

Synthesis of PHAs with tailored properties is a difficult technological task, and production of a PHA of definite composition should be based on fundamental knowledge of how a certain PHA is synthesized and how the chemical structure of the polymer influences its physicochemical properties. There are several ways to produce PHAs consisting of monomers with different length of the carbon chain: using genetically modified PHA producing strains, with genes controlling the key enzymes of PHA synthesis ( $\beta$-ketothiolase, acetoacetyl-CoA reductase, PHA-synthase) taken from microorganisms of different taxa and introduced into them, and based on the knowledge of the mechanisms of PHA synthesis by natural producers, which are influenced by culture conditions.

A very promising but insufficiently studied PHA is the poly(3-hydroxybutyrate-co-4hydroxybutyrate) (P(3HB-co-4HB)) copolymer. PHAs of this type are biodegraded in vivo and in the environment at high rates and exhibit better elongation at break and higher tensile strength than most of the well-known polymers of this class (Martin, Williams, 2003; Freier, 2006; Chanprateep, 2010). The ability of such microorganisms as Cupriavidus necator (previously known as Wautersia eutropha, Ralstonia eutropha, Alcaligenes eutrophus) (Nakamura et al., 1992), Alcaligenes latus (Hiramitsu et al., 1993), Comamonas testosteronii
(Renner et al., 1996), Comamonas acidovorans (Saito, Doi, 1994), Hydrogenophaga pseudoflava (Choi et al., 1999), Chromobacterim sp (Kimura et al., 1999), Rhodococcus rubber (Haywood et al., 1991), Delftia acidovorans (Hsieh et al., 2009) to synthesize PHAs of this type when grown on the media containing 4-hydroxybutyric acid, $\gamma$-butyrolactone or 1,4-butanediol as carbon substrate was reported in a number of studies in the 1990s. The inhibiting effect of these substrates, however, reduces both total biomass production and copolymer yields.

In recent years, this representative of PHAs has received much attention. Recombinant Escherichia coli, Aeromonas hydrophila, Pseudomonas putida, Ralstonia eutropha H16 (Zhang et al., 2009; Li et al., 2010) and wild-type strains Cupriavidus sp. USMAA1020 (Amirul et al., 2008), $R$. eutropha A-04 (Chanprateep et al., 2008), Cupriavidus sp. USMAA2-4 (Ramachandran et al., 2011), R.eutropha KCTC 2662 (Park et al., 2011) have been described as novel producers of $\mathrm{P}(3 \mathrm{HB}-\mathrm{co}-4 \mathrm{HB})$.

The objective of this study was to research the conditions of the $\mathrm{P}(3 \mathrm{HB}-\mathrm{co}-4 \mathrm{HB})$ synthesis by natural strains of hydrogen-oxidizing bacteria and determined the effect of the composition on the properties of the copolymer and the resulted products.

\section{Materials and Methods}

Two strains of hydrogen-oxidizing bacteria-Ralstonia eutropha B5786 (Stasishina, Volova, 1992) and Cupriavidus eutrophus B10646 (registered in the Russian Collection of Industrial Microorganisms (VKPM)) were batch cultured in 1.0-L glass flasks, which were $50 \%$ filled with the culture, under strict aseptic conditions, on a "New Brunswick" temperaturecontrolled shaker(USA); the cultures were grown on Schlegel mineral salt medium. Autotrophic cultures were grown on the $\left(\mathrm{CO}_{2}, \mathrm{H}_{2}, \mathrm{O}_{2}\right)$ gas 
mixture as carbon and energy source. Air was evacuated from the flasks with a compressor, and the gas mixture was supplied from a gasholder, via airtight hoses. The proportions of $\mathrm{CO}_{2}, \mathrm{O}_{2}$ and $\mathrm{H}_{2}$ in the gas mixture were 1:2:7 $(\mathrm{v} / \mathrm{v})$. Heterotrophic cultures were grown on fructose or butyric acid. Cells were cultured in two phases - in nitrogen-limited medium in the first and nitrogen-free one in the second, at $\mathrm{pH} 7.0$ and temperature $30{ }^{\circ} \mathrm{C}$, in accordance with our previously developed procedure (Volova et al., 1992). Synthesis of monomers 4-hydroxybutyrate (4HB) was induced by the addition of $\gamma$-butyrolactone (Fluka). The culture was added with $\gamma$-butyrolactone with varied frequency and in varied amounts. The duration of the cultivation depended on carbon nutrition conditions and varied from $72 \mathrm{~h}$ to $96 \mathrm{~h}$.

Biomass yield was determined from dry mass and optical parameters of the culture. Polymer content and PHA composition was determined with a gas chromatograph-mass spectrometer (GC/MS, model GCD Plus, Hewlett Packard, USA) Percentages of the monomers in $(\mathrm{P}(3 \mathrm{HB}-\mathrm{co}-4 \mathrm{HB})$ were quantified based on mass spectra, and more accurate quantification was attained by taking ${ }^{1} \mathrm{H}-\mathrm{NMR}$ spectra of copolymer solutions in $\mathrm{CDCl}_{3}$ using an Avance III 600 NMR spectrometer (Bruker, Germany). Current concentrations of salts of alkanoic acids and $\gamma$-butyrolactone in the culture were analyzed using gas chromatography. Fructose concentration in the medium was measured using the resorcinol method (Ermakov et al., 1972).

$\mathrm{X}$-ray structure analysis and determination of crystallinity of PHA samples were performed using a D8 Advance X-ray spectrometer (Bruker, Germany) (graphite monochromator on a reflected beam) in a scan-step mode, with a $0.04^{\circ}$ step and exposure time $2 \mathrm{sec}$, to measure intensity at point. The instrument was operating at $40 \mathrm{kV} \times$ $40 \mu \mathrm{A}$. Thermal properties of biopolymers were examined using differential scanning calorimetry with a NETZSCH analyzer (Germany). Each sample of mass $\sim 2 \mathrm{mg}$ was shaped as a disc of diameter $5 \mathrm{~mm}$, inserted into an aluminum capsule with a small hole, and heated at $5 \mathrm{~K} / \mathrm{min}$. Melting point, devitrification temperature, and thermal degradation temperature were determined from DSC curves at the given heating rate.

Molecular weight was determined by gel permeation chromatography at a temperature of $40{ }^{\circ} \mathrm{C}$, using a Waters chromatographic system (a Waters 151 isocratic pump, a Reodyne 7725i injector, and a Waters 2414 refractometric detector) and columns Styragel HR4E and HR5. Chloroform was used as eluent, with the flow rate $0.8 \mathrm{ml} / \mathrm{min}$. The system was calibrated using low polydispersity polysterene standards supplied by Sigma (USA).

The number-average molecular weight of the PHA was determined as

$$
\mathrm{M}_{\mathrm{n}}=\Sigma\left(\mathrm{N}_{\mathrm{i}} \cdot \mathrm{M}_{\mathrm{i}} / \mathrm{N}\right),
$$

where $N_{\mathrm{i}}$ is the number of molecules of mass $I ; N$ is the total number of molecules; $M_{\mathrm{i}}$ is the mass of molecules of length $I$.

The weight average molecular weight of the PHA was determined as

$$
\mathrm{M}_{\mathrm{w}}=\Sigma\left(\mathrm{w}_{\mathrm{i}} \cdot \mathrm{M}_{\mathrm{i}}\right),
$$

where $w_{\mathrm{i}}$ is the portion of the mass $\left(\mathrm{w}_{\mathrm{i}}=\mathrm{N}_{\mathrm{i}} \mathrm{M}_{\mathrm{i}} / \Sigma\right.$ $\left(\mathrm{N}_{\mathrm{i}} \cdot \mathrm{M}_{\mathrm{i}}\right)$.

Polydispersity, which provides an estimate of the proportions of fragments with different polymerization abilities in the polymer, was calculated from the formula

$$
\mathrm{PD}=\mathrm{M}_{\mathrm{w}} / \mathrm{M}_{\mathrm{n}}
$$

Experiments were done in three replicates. The results were analyzed statistically by 
conventional methods, using the standard software package of Microsoft Excel.

\section{Results}

In the autotrophic culture of $R$. eutropha B5786 grown in flasks on a shaker under nitrogen deficiency, using single-carbon substrate $\left(\mathrm{CO}_{2}\right)$, the biomass yield and the polymer content after 72-h fermentation amounted to $6.1 \mathrm{~g} / \mathrm{L}$ and $65.4 \%$ of dry cell weight (DCW), respectively (Table 1). The polymer synthesized by $R$.eutropha B5786 on single-carbon substrate contained $99.2 \mathrm{~mol} \%$ of $3 \mathrm{HB}$ and $0.8 \mathrm{~mol} \%$ of 3-hydroxyvalerate $(3 \mathrm{HV})$. Previously we reported that cultivation of bacteria in flasks for longer periods and the use of advanced fermentation equipment can increase polymer yield to $85-90 \%$ of DCW (Volova, Kalacheva, 2005). The main purpose of this study, however, was to find out whether this strain is able to synthesize a PHA containing 4-hydroxybutyrate (4HB) and what growth conditions are necessary for this. Biomass yield was considered as a secondary issue, so the duration of experiments with autotrophic culture in flasks did not exceed $70 \mathrm{~h}$.

Taking into account the data on the toxicity of $\gamma$-butyrolactone (Nakamura et al., 1992), we studied the effect of this supplementary substrate on R. eutropha B5786 growth and PHA synthesis using $\gamma$-butyrolactone concentration from 0.5 $\mathrm{g} / \mathrm{L}$ to $4.0 \mathrm{~g} / \mathrm{L}$. Results of PHA biosynthesis and incorporation of $4 \mathrm{HB}$ into the copolymer, using mixed carbon source $\left(\mathrm{CO}_{2}+\gamma\right.$-butyrolactone $)$ are shown in Table 1: $\gamma$-butyrolactone inhibited polymer synthesis and accumulation. Higher concentrations of $\gamma$-butyrolactone in the medium did not increase $4 \mathrm{HB}$ proportion in the copolymer; moreover, they inhibited transformation of $\gamma$-butyrolactone to $4 \mathrm{HB}$. While with $0.5 \mathrm{~g} / \mathrm{L}$ of $\gamma$-butyrolactone in the medium the degree of its transformation into $4 \mathrm{HB}$ reached 0.21 , at concentration of $4 \mathrm{~g} / \mathrm{L}$ it dropped below 0.02 .
The amount of $\gamma$-butyrolactone added to the culture did not affect biomass yield, which was not higher than $5.0 \mathrm{~g} / \mathrm{L}$, or $25 \%-30 \%$ lower than in the control culture (with $\mathrm{CO}_{2}$ as sole substrate). Investigation of the influence of $\gamma$-butyrolactone on polymer synthesis showed a dose-dependent reduction in the intracellular concentration of the polymer; the highest polymer yield $(39.9 \%$ of DCW) was attained in the experiment with a single addition of $0.5 \mathrm{~g} / \mathrm{L}$ of $\gamma$-butyrolactone. Polymer synthesized under these conditions contained three monomers: $3 \mathrm{HB}$ as a major component, $4 \mathrm{HB}$, and minor amounts of $3 \mathrm{HV}$. Monomer 4HB was detected in all samples, with the highest percentage amounting to $6.3 \mathrm{~mol} \%$ (Table 1).

To reduce the toxic effect of $\gamma$-butyrolactone on the culture, it was added in several portions. By varying the size of the dose of $\gamma$-butyrolactone added to the culture and the duration of the subsequent cultivation, we managed to increase the total yield of bacterial cells and the polymer yield. When the $\gamma$-butyrolactone dose $(6 \mathrm{~g} / \mathrm{L})$ was divided into two portions, the polymer yield reached $55.7 \%$ of DCW and the total culture productivity was not decreased, but the $4 \mathrm{HB}$ fraction did not grow, amounting to not more than $6 \mathrm{~mol} \%$. When the dose of $\gamma$-butyrolactone of $9.0 \mathrm{~g} / \mathrm{L}$ was divided into three portions $(3 \mathrm{~g} / \mathrm{L}$ each) and added every $8 \mathrm{~h}$, the polymer yield was $50.3 \%$ of DCW, the total biomass yield $4.0 \mathrm{~g} / \mathrm{L}$, and the $4 \mathrm{HB}$ fraction did not rise above $6 \mathrm{~mol} \%$ (Table 1).

In the culture of $R$. eutropha B5786 grown heterotrophically, with fructose as the main substrate, theinhibitory effect of $\gamma$-butyrolactone was less pronounced (Table 1). Doses of $\gamma$-butyrolactone added in one portion were 2.0 , 6.0 and $10.0 \mathrm{~g} / \mathrm{L}$. Inhibition of cell growth was only recorded with the highest concentration of $\gamma$-butyrolactone: biomass yield was as low as $4.5 \mathrm{~g} / \mathrm{L}$. At the two other concentrations, 
Table 1. Content and composition of polyhydroxyalkanoates synthesized by bacteria Ralstonia eutropha B5786 in different conditions (experiments were done in three replicates)

\begin{tabular}{|c|c|c|c|c|c|c|}
\hline \multirow{2}{*}{$\begin{array}{c}\text { Concentration of } \\
\gamma \text {-butyrolactone, } g / 1\end{array}$} & \multirow{2}{*}{ Hours } & \multirow{2}{*}{$\begin{array}{l}\text { Biomass yield, } \\
\mathrm{g} / \mathrm{l}\end{array}$} & \multirow{2}{*}{$\begin{array}{l}\text { Polymer content, } \\
\% \text { of DCW }\end{array}$} & \multicolumn{3}{|c|}{ Polymer composition, mol \% } \\
\hline & & & & $3 \mathrm{HB}$ & $3 \mathrm{HV}$ & $4 \mathrm{HB}$ \\
\hline \multicolumn{7}{|c|}{ Autotrophic conditions $\left(\mathrm{CO}_{2}\right)$} \\
\hline 0 & 72 & $6.1 \pm 0.2$ & $65.4 \pm 4.2$ & 99.2 & 0.8 & - \\
\hline 0.5 & 72 & $4.2 \pm 0.3$ & $39.9 \pm 1.7$ & 93.3 & 0.4 & 6.3 \\
\hline 1.5 & 72 & $4.3 \pm 0.2$ & $24.9 \pm 1.9$ & 93.6 & 0.4 & 6.0 \\
\hline 2.0 & 72 & $4.6 \pm 0.2$ & $13.9 \pm 0.7$ & 95.7 & 0.5 & 3.8 \\
\hline 4.0 & 72 & $4.4 \pm 0.4$ & $12.0 \pm 0.9$ & 98.7 & 0.7 & 0.6 \\
\hline $6.0(3+3)^{*}$ & 72 & 5.9 & 55.7 & 93.4 & 0.7 & 5.9 \\
\hline $9.0(3+3+3)^{* *}$ & 72 & 6.0 & 50.3 & 93.5 & 0.6 & 5.9 \\
\hline \multicolumn{7}{|c|}{ Heterotrophic conditions (fructose) } \\
\hline 2.0 & 96 & $7.5 \pm 0.4$ & $57.3 \pm 3.4$ & 98.6 & 0.5 & 0.9 \\
\hline 6.0 & 96 & $7.0 \pm 0.3$ & $50.6 \pm 4.1$ & 97.9 & 0.7 & 1.4 \\
\hline 10.0 & 96 & $4.5 \pm 0.3$ & $56.7 \pm 2.9$ & 98.0 & 0.4 & 1.6 \\
\hline $6.0(3.0+3.0)^{*}$ & 96 & 7.4 & 78.1 & 95.6 & 0.6 & 3.8 \\
\hline $9.0(3.0+3.0+3.0)^{* *}$ & 96 & 7.2 & 65.9 & 95.3 & 0.6 & 4.1 \\
\hline \multicolumn{7}{|c|}{ Heterotrophic conditions (butyric acid) } \\
\hline $6.0(3.0+3.0)^{* *}$ & 96 & 7.1 & 81.7 & 95.1 & 0.5 & 4.4 \\
\hline
\end{tabular}

biomass yield was similar to that in the control, reaching 7.0-7.5 $\mathrm{g} / \mathrm{L}$, after cultivation for 96 h. Assimilation of $\gamma$-butyrolactone occurred at a higher rate than in the autotrophic culture, and in $34 \mathrm{~h}$ after $\gamma$-butyrolactone was added, its concentration in the culture did not exceed 0.1-0.2 g/L. In the experiment with the inhibitory concentration of $\gamma$-butyrolactone, polymer yield amounted to $56.7 \%$ of DCW, but the 4HB fraction of the polymer was small $-1.6 \mathrm{~mol} \%$. With $6.0 \mathrm{~g} / \mathrm{L}$ and $2.0 \mathrm{~g} / \mathrm{L}$ of $\gamma$-butyrolactone added to the culture, polymer yield amounted to $50.6 \%$ and $57.3 \%$ of DCW, but the polymer contained less than $2 \mathrm{~mol} \%$ of 4HB. In experiments with $\gamma$-butyrolactone added in several portions, polymer yield was increased to $65.9-70.1 \%$ of $\mathrm{DCW}$, but the $4 \mathrm{HB}$ fraction grew insignificantly - to 3.8-4.1 $\mathrm{mol} \%$ (Table 1).
The use of butyric acid (butyric acid sodium salt) instead of fructose increased copolymer yield and improved its composition. As butyric acid concentrations above $4.0 \mathrm{~g} / \mathrm{L}$ inhibited cell growth, the concentration of butyric acid was 1-2 g/l. Cultivation of $R$. eutropha B5786 on the medium containing butyric acid and $6 \mathrm{~g} / \mathrm{L}$ of $\gamma$-butyrolactone (added in two portions) resulted in polymer yield of $81.7 \%$ of DCW. The fraction of $4 \mathrm{HB}$, however, remained low - not higher than $4.4 \mathrm{~mol} \%$ (Table 1 ).

Thus, by varying the conditions of carbon nutrition, including the main carbon substrate and its concentration, and the mode of feeding the supplementary substrate ( $\gamma$-butyrolactone) into the culture, we managed to maximize the yields of the polymer and total biomass of R. eutropha B5786 however the content of 4HB in copolymer was low. 
Further experiments were done with the strain C. eutrophus B10646 which has the increased sustainability to $\gamma$-butyrolactone is compared to $R$. eutropha B5786. The highest concentration of $\gamma$-butyrolactone for this strain is $15-20 \mathrm{~g} / \mathrm{L}$. In the culture of C. eutrophus B10646 grown autotrophically and heterotrophically, a higher content of $4 \mathrm{HB}$ in the copolymer was obtained (up to $15 \mathrm{~mol} \%$ ), which on the background of the higher indexes of biomass yield and total yield of the copolymer made $6-7 \mathrm{~g} / \mathrm{L}$ and $81-85 \%$, correspondingly.

The mode of growing C. eutrophus B10646 in the medium containing the propionic acid as the main substrate in the concentration $2 \mathrm{~g} / \mathrm{L}$ and $\gamma$-butyrolactone provided synthesis of three component polymer containing $8.1 \mathrm{~mol} \%$ of 4HB and $35.2 \mathrm{~mol} \%$ of $3 \mathrm{HV}$ besides 3HB. Using butyric acid with $\gamma$-butyrolactone as the carbon source resulted in higher production of polymer in the culture of C. eutrophus B10646 (Fig. 1). Biomass yield and polymer content varied depending on the $\gamma$-butyrolactone concentration. The yields were $6.2-8.2 \mathrm{~g} / \mathrm{L}$ and $72-89.7 \%$ of DCW, correspondingly; whereas the content of
4HB varied in the range of $8.7-24.3 \mathrm{~mol} \%$. Using the strain of C. eutrophus B10646 with the higher tolerance to the $\gamma$-butyrolactone, effect of both the copolymer $\mathrm{P}(3 \mathrm{HB}-$ co-4HB) strain and the single-carbon substrate allowed not only to increase the content of 4HB in the copolymer, but also to reduce the time of bacteria cultivation.

Growing of C. eutrophus B10646 bacteria in the medium contained the butyric acid (or fructose) as the main substrate and addition of $\gamma$-butyrolactone in various concentration (from 2.0 to $10.0 \mathrm{~g} / \mathrm{L}$ ) allowed to fulfil the process with the total yields of biomass and copolymer within 29-32 hours of cultivation, i.e., up to $25-32 \mathrm{~g} / \mathrm{L}$ and $88-95 \%$ of DCW, with $15-20 \mathrm{~mol} \%$ of $4 \mathrm{HB}$ in the copolymer. Composition of the produced and purified samples of $\mathrm{P}(3 \mathrm{HB}-c o-4 \mathrm{HB})$ were analyzed by the ${ }^{1} \mathrm{H}-\mathrm{NMR}$ method which proved the presence of $4 \mathrm{HB}$ in the copolymer. The ${ }^{1} \mathrm{H}$ NMR spectra of the copolymer samples with $4 \mathrm{HB}$ incorporation at $8.7 \mathrm{~mol} \%$ and $16 \mathrm{~mol} \%$ are presented in Fig. 2.

Thus, the substitution of the strain $R$. eutropha B5786 by the strain C. eutrophus B10646 and the developed mode of proportions

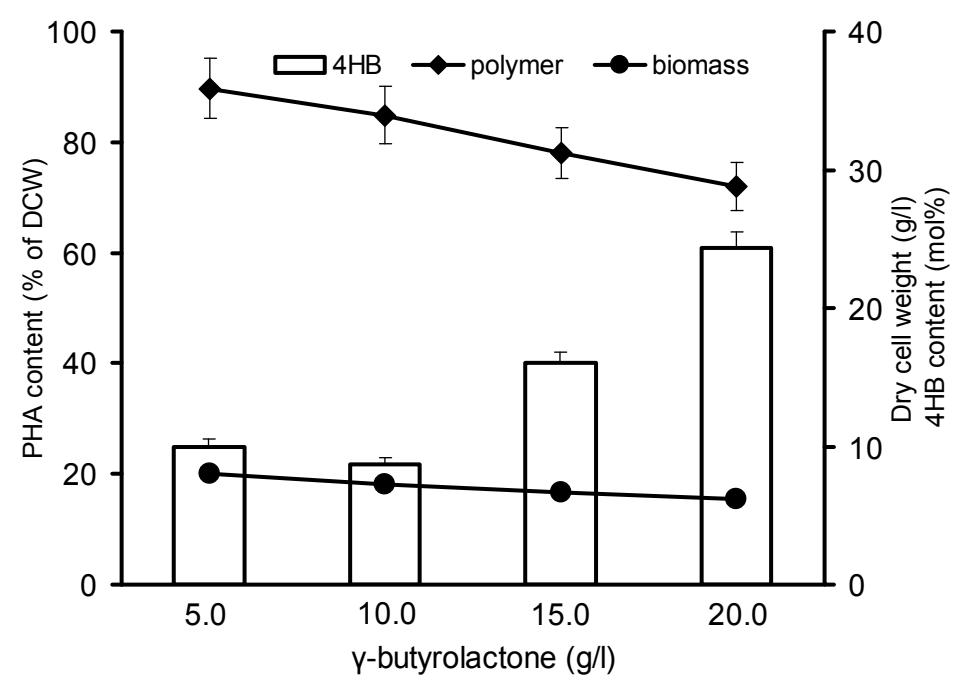

Fig. 1. Effect of different concentrations of $\gamma$-butyrolactone on the $\mathrm{P}(3 \mathrm{HB}-\mathrm{co}-4 \mathrm{HB})$ production of Cupriavidus eutrophus B10646 under heterotrophic (substrate - butyric acid) conditions 


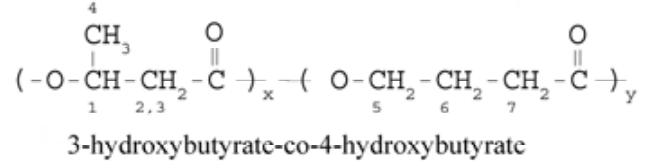

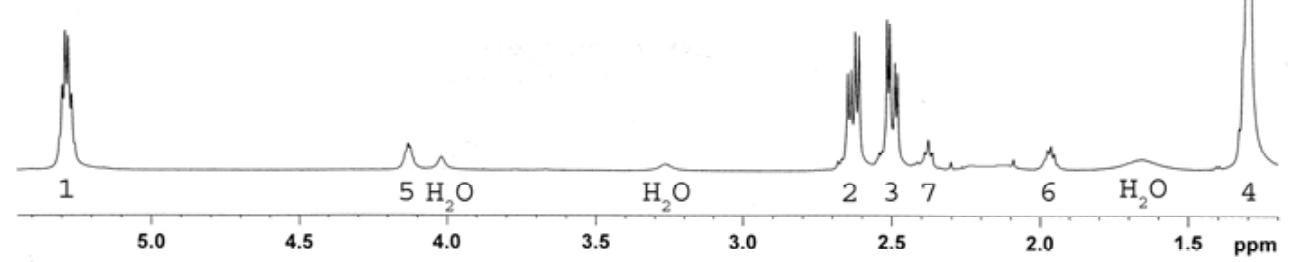

б

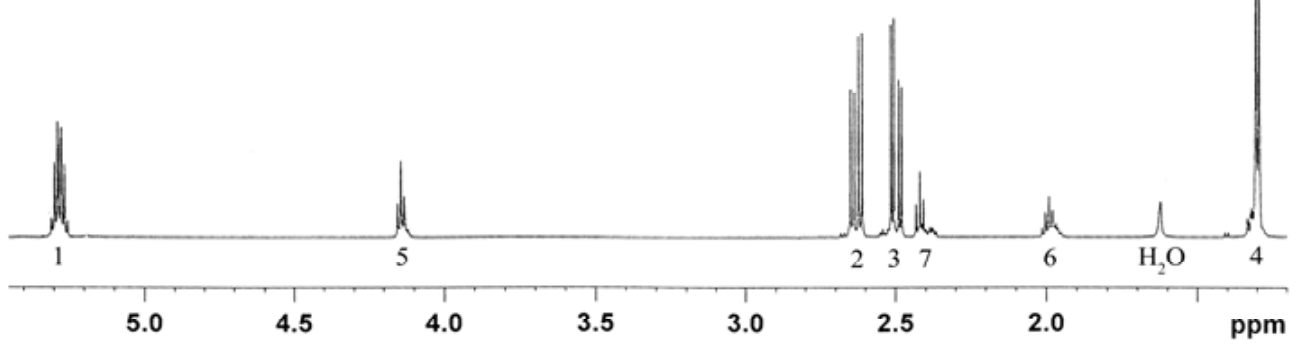

Fig. 2. ${ }^{1} \mathrm{H}-\mathrm{NMR}$ spectrum of the $\mathrm{P}(3 \mathrm{HB}-\mathrm{co}-4 \mathrm{HB})$ with content of $4 \mathrm{HB} 8.7 \mathrm{~mol} \%$ (a) and $16 \mathrm{~mol} \%$ (b) 
of $\gamma$-butyrolactone in the culture provided significantly higher values of the three key indexes: biomass yield, copolymer concentration in cells and content of 4HB.

The properties of the set of synthesized and highly purified samples of $\mathrm{P}(3 \mathrm{HB}-\mathrm{co}-4 \mathrm{HB})$ were studied using modern physical methods. Using the gel permeation chromatography, the molecular mass of the set of the synthesized samples of copolymers $\mathrm{P}(3 \mathrm{HB}-c o-4 \mathrm{HB})$ was determined (Table 2). No influence of this parameter on the molecular mass and the polydispersity of the copolymer was detected in the studied range of the monomers ratio in the copolymer (the incorporation of $4 \mathrm{HB}$ varied from 8.7 to $24.3 \mathrm{~mol} \%$ ). The number average mass in the set of samples varied in the range from 230 to $480 \mathrm{kDa}$, the weight average molecular mass amounted to $540-1110 \mathrm{kDa}$; the polydispersity varied from 1.91 to 2.76 with no clear correlation with the content of 4HB in the copolymer.

It has been demonstrated that the incorporation of $4 \mathrm{HB}$ influenced significantly the ratio of crystalline and amorphous phases in the copolymer (to the higher extent if compared to 3-hydroxyvalerate and 3-hydroxyhexanoate), sufficiently reducing its crystallinity (Table 2). For the first time we managed to obtain the samples of PHA with the lowered degree of crystallinity (from $44 \%$ to $12 \%$ ).

The melting temperature of the produced samples of $\mathrm{P}(3 \mathrm{HB}-\mathrm{co}-4 \mathrm{HB})$ was lower $\left(168.9-172.5^{\circ} \mathrm{C}\right)$ in comparison to poly $(3-$ hydroxybutyrate) $\left(180^{\circ} \mathrm{C}\right)$. However, no relation between the $4 \mathrm{HB}$ content in the range from 8.7 mol \% to $17 \mathrm{~mol} \%$ and the melting temperature has been determined. The temperature of thermal degradation of various copolymer samples varied in the range from $264^{\circ} \mathrm{C}$ to $286^{\circ} \mathrm{C}$ and did not depend on the content of 4HB.

\section{Discussion}

Analysis of the up-to-date literature witnesses the activity of the research aimed at the synthesis of copolymer P(3HB-co-4HB). This type of PHA characterized by high elasticity and strength, as well as quicker and regulated speed of biodegradation, attracts the attention of the researchers who develop the products intended for the biomedical field. For the present moment the company Metabolix (USA) has developed and produced a line of products made out of this copolymer in the form of suture material, films and reticular implants. For successful production of this type of PHA many research teams isolate new strains-producers, improve the fermentation technology using various compounds as growth

Table 2 Physical characterization of $\mathrm{P}(3 \mathrm{HB}-\mathrm{co}-4 \mathrm{HB})$ produced by Cupriavidus eutrophus $\mathrm{B} 10646$

\begin{tabular}{c|c|c|ccc}
\hline $\begin{array}{c}\text { 4HB content, } \\
\text { mol \% }\end{array}$ & $\left.\mathrm{M}_{\mathrm{n}} \times 10^{3}\right) \mathrm{Da}$ & $\mathrm{PD}$ & Crystallinity, \% & $\begin{array}{c}\text { Melting temperature } \\
\left(\mathrm{T}_{\mathrm{m}}\right),{ }^{\circ} \mathrm{C}\end{array}$ & $\begin{array}{c}\text { Degradation } \\
\text { temperature }\left(\mathrm{T}_{\mathrm{d}}\right),{ }^{\circ} \mathrm{C}\end{array}$ \\
\hline 0 & $760 \pm 15$ & $1.60 \pm 0.03$ & 76 & 180 & 280 \\
8.7 & $230 \pm 2$ & $2.76 \pm 0.03$ & 44 & 171 & 286 \\
10.7 & $480 \pm 9$ & $2.32 \pm 0.06$ & 43 & 171.9 & 268 \\
14.9 & $320 \pm 7$ & $2.65 \pm 0.04$ & 44 & 168.9 & 264 \\
16.0 & $370 \pm 5$ & $2.59 \pm 0.04$ & 43 & 171.3 & 279 \\
17.0 & $370 \pm 12$ & $2.31 \pm 0.06$ & 25 & 172.5 & 271 \\
24.3 & $285 \pm 5$ & $1.91 \pm 0.01$ & 12 & - & 274 \\
\hline
\end{tabular}

- not identified 
substrates. Thus, Li with co-authors (2010) has determined that the recombinant strain E. coli containing the plasmid with the genes incorporated into the succinate degradation out of Clostridium kluyveri, and the directional genes of the poly(3hydroxybutyrate) synthesis out of $R$. eutropha, can synthesize with higher yields (up to $70 \%$ of $\mathrm{DCW}$ ) of copolymer P(3HB-co-4HB). Among the natural producers various bacteria have been described. Recently new highly productive strains have been isolated from soil in Thailand and bottom sediments of the lake in Malaysia which have been identified correspondingly as $R$. eutropha A-04 (Chanprateep et al., 2008) and Cupriavidus sp. USMAA1020 (Amirul et al., 2008), synthesizing copolymers $\mathrm{P}(3 \mathrm{HB}-$ co4HB) using $\gamma$-butyrolactone, 1,4-butanediol or 4-hydroxybutyrate acid. If $R$. eutropha A-04 is grown on 4-hydroxybutyric acid the maximum incorporation of $4 \mathrm{HB}$ amounts to $52 \mathrm{~mol} \%$ with $22 \%$ of polymer of DCW biomass. The maximum content of the copolymer (59\% of the dry biomass) was obtained using the mixture of 4-hydroxybutyric acid and butyric acid (1:1), nevertheless, the incorporation of $4 \mathrm{HB}$ did not exceed 24 mol \% (Chanprateep et al., 2008). When the strain Cupriavidus sp. USMAA1020 was grown on $\gamma$-butyrolactone, 4 - hydroxybutyric acid and 1,4-butanediol, the best substrate for growth and synthesis of the polymer $(4.96 \mathrm{~g} / \mathrm{L}$ and $58.7 \%$ of DCW, correspondingly) for this strain was 1,4-butanediol with $32 \mathrm{~mol} \%$ of $4 \mathrm{HB}$ (Amirul et al., 2008). Higher values of $4 \mathrm{HB}$ in the copolymer (over $80 \mathrm{~mol} \%$ ) were obtained using the mixture of 1,4-butanediol and $\gamma$-butyrolactone, nevertheless, the biomass and the polymer content reduced therefore to $1.9 \mathrm{~g} / \mathrm{L}$ and $16 \%$ of the dry weight (Vigneswari et al., 2010). The copolymer with the same high content of 4HB was produced during the cultivation of another strain of bacteria Wautersia eutropha H16 in the medium which besides 4-hydroxybutyric acid also contained amino acids L-alanine and L-threonine, however, the biomass yield was significantly higher, about $12 \mathrm{~g} / \mathrm{L}$, but the content of the polymer did not exceed $42 \%$ of DCW (Kimura et al., 2008). Moreover, Nakamura and co-authors (1992) proved the possibility to produce homopolymer $\mathrm{P}(4 \mathrm{HB})$, but the content of homopolymer did not exceed $2 \%$. To reduce the cost of the polymer the research on using cheaper carbon sources for the copolymer $\mathrm{P}(3 \mathrm{HB}-c o-4 \mathrm{HB})$ synthesis have been carried out, including oleic acid and saturated fatty acids with even amount of carbon atoms (C12-C18) (Rahayu et al., 2008; Ramachandran et al., 2011), alkanediols (Vigneswari et al., 2009), worked out palm oil (Rao et al., 2010), soy bean oil (Park, Kim, 2011), nevertheless, no significant yields of the copolymer P(3HB-co-4HB) on these substrates have been obtained.

Thus, using the recently produced, new natural strains and recombinant producers the possibility of synthesizing the copolymer $\mathrm{P}(3 \mathrm{HB}-$ co-4HB) with different yields (from $2 \%$ to $70 \%$ of $\mathrm{DCW}$ ) of the copolymer with the content of $4 \mathrm{HB}$ up to $100 \mathrm{~mol} \%$ at various yields of the biomass yield (from 2 to $12 \mathrm{~g} / \mathrm{L}$ ) has been determined.

In this work the results of studying the synthesis of the copolymer $\mathrm{P}(3 \mathrm{HB}-c o-4 \mathrm{HB})$ by two natural strains of hydrogen-oxidizing bacteria are presented. The analysis of the capability of the strain $R$. eutropha B5786 characterized by the high yields of poly(3-hydroxybutyrate) (up to $90 \%$ of DCW) at different substrates including the synthesis-gas (Volova, Voinov, 2004) and the copolymers poly(3-hydroxybutyrate-co-3hydroxyvalerate) (Volova et al., 2007) and 3- and 4-component PHA formed by the monomers C4, C5, C6, C7 (Volova et al., 2006) has shown that content of the monomer in the copolymer did not exceed $4 \mathrm{~mol} \%$, the maximum biomass production and copolymer content amounted for 6 $\mathrm{g} / 1$ and $60 \%$ of DCW, correspondingly, due to the pronounced inhibiting effect of $\gamma$-butyrolactone 
on this strain. Attempts to change the dosage mode of $\gamma$-butyrolactone (fractional adding) allowed to increase the total biomass and the copolymer production, unfortunately, the content of 4HB did not exceed $6 \mathrm{~mol} \%$ as in autotrophic, so in heterotrophic conditions.

As shown in the presented work, for the strain $R$. eutropha B5786 with concentration of $\gamma$-butyrolactone exceeding $6 \mathrm{~g} / \mathrm{L}$ in the culture, the decrease of the yield and copolymer production is observed due to the inhibiting effect. Another studied strain C. eutrophus B10646 selected for the sustainability to $\gamma$-butyrolactone influence (registered in the collection of the Russian Collection of Industrial Microorganisms in 2010) allowed us to obtain higher results. Unlike the strain $R$. eutropha B5786, $\gamma$-butyrolactone with concentration up to $15 \mathrm{~g} / \mathrm{L}$ in the medium did not inhibited the growth and the synthesis of the polymer in the strain C. eutrophus B10646. The fulfilled mode of growing allowed to obtain good results in the biomass production (to 7-8 $\mathrm{g} / \mathrm{L}$ of 72 hours of cultivation) with the yield of copolymer up to $80-90 \%$ of DCW and the content of 4HB monomer up to $17 \mathrm{~mol} \%$. These results can be compared with the data of the other research obtained by Amirul et al. (2008) during the cultivation of the strain Cupriavidus sp. USMAA1020 and Chanprateep et al. (2008) during the cultivation of the strain $R$. eutropha A-04.

The samples synthesized in the experimental amounts with the different ratio of monomers $3 \mathrm{HB}$ and $4 \mathrm{HB}$ purified to the homogeneous condition allowed to study their properties: molecular mass, degree of crystallinity and temperature characteristics. At the same time no relation between the $4 \mathrm{HB}$ content and the copolymer's molecular mass has been determined. This confirms the previous results that there is no correlation between the composition of PHA and the molecular mass (Volova, Kalacheva, 2005).
The absence of correlation between the molecular weight of the polymer and the $4 \mathrm{HB}$ content has been also demonstrated for Comamonas acidovorans (Mitomo et al., 2001). Nevertheless, Vigneswari et al. (2009) has demonstrated the inverse dependence between the 4HB content and the molecular mass for Cupriavidus sp. USMAA1020.

The crystallinity degree of the copolymers $\mathrm{P}(3 \mathrm{HB}-\mathrm{co}-4 \mathrm{HB})$ with the content of the $4 \mathrm{HB}$ ranging from 8.7 to $16 \mathrm{~mol} \%$ amounted to $43-$ $44 \%$ which corresponds to the results of other authors (Doi et al., 1990; Nakamura et al., 1992; Tsuge, 2002). Thus, Mitomo et al. (2001) has demonstrated that the crystallinity degree of the copolymer with the $4 \mathrm{HB}$ content of 19,38 and $65 \mathrm{~mol} \%$ amounted for 40,18 and $27 \%$, correspondingly. The authors have assumed that the crystallinity degree of the copolymer is minimum when the $4 \mathrm{HB}$ content is $40-50$ mol \% (Mitomo et al., 2001). Nevertheless, according to the data of the other authors the minimum crystallinity degree of $17-18 \%$ has been determined for the polymers with the 4HB content of 78-82 mol \% (Saito, Doi, 1994).

There is uncertainty of the obtained data in the literature for the melting temperature of the $\mathrm{P}(3 \mathrm{HB}-\mathrm{co}-4 \mathrm{HB})$ samples. According to the data of some authors the melting temperature of the samples with $4 \mathrm{HB}$ content of $7 \mathrm{~mol} \%$, $11 \mathrm{~mol} \%$ and $15 \mathrm{~mol} \%$ amounted to 173,169 and $160.8^{\circ} \mathrm{C}$ correspondingly (Kunioka et al., 1989; Doi, 1990; Rao et al., 2010), when in the other papers the melting temperature of the samples with the similar amount of $4 \mathrm{HB}$ is considerably lower: $114^{\circ} \mathrm{C}$ and $131.5^{\circ} \mathrm{C}$ (Xie, Chen, 2008; Li et al., 2010). In our work the melting temperature for the set of $\mathrm{P}(3 \mathrm{HB}-\mathrm{co}$ 4HB) samples amounted to $168-171.9{ }^{\circ} \mathrm{C}$. The gap between the melting temperature and the temperature of thermal degradation for the set of the studied samples made $95.1-115^{\circ} \mathrm{C}$. We 
have not found any references regarding the temperature of thermal degradation of $\mathrm{P}(3 \mathrm{HB}$ co-4HB).

Thus, $\mathrm{P}(3 \mathrm{HB}-\mathrm{co}-4 \mathrm{HB})$ was produced by $R$. eutropha B5786 and C. eutrophus B10646 under autotrophic and heterotrophic conditions using $\gamma$-butyrolactone as source of 4HB. It was shown that $C$. eutrophus $\mathrm{B} 10646$ possesses the increased sustainability to the $\gamma$-butyrolactone influence. The fulfilled mode of growing of C. eutrophus B10646 allowed to obtain good results in the biomass production (to $7-8 \mathrm{~g} / \mathrm{L}$ of 72 hours of cultivation) with the yield of copolymer up to 80$90 \%$ of DCW and the content of 4HB monomer in it to $17 \mathrm{~mol} \%$ ). A set of highly purified samples of $\mathrm{P}(3 \mathrm{HB}-c o-4 \mathrm{HB})$ with different content of 4HB was produced and their physicochemical properties were studied.

\section{Acknowledgements}

This study was financially supported by the Projects of SB RAS No 93 and 96 and the Project "Biotechnologies of novel biomaterials" (Agreement № 11.G34.31.0013) in accordance with Resolution No. 220 of the Government of the Russian Federation of April 9, 2010, "On measures designed to attract leading scientists to the Russian institutions of higher learning".

\section{References}

Amirul A.A., Yahya A.R.M., Sudesh K., Azizan M.N.M., Majid M.I.A. (2008) Biosynthesis of poly(3-hydroxybutyrate-co-4-hydroxybutyrate) copolymer by Cupriavidus sp. USMAA1020 isolated from lake Kulim, Malaysia. Bioresource Technol. 99: 4903-4909

Chanprateep S. (2010) Current trends in biodegradable polyhydroxyalkanoates. J. Biosci. Bioeng. 110: 621-632

Chanprateep S., Katakura Y., Visetkoop S., Shimizu H., Kulpreecha S., Shioya S. (2008) Characterization of new isolated Ralstonia eutropha strain A-04 and kinetic study of biodegradable copolyester poly(3-hydroxybutyrate-co-4-hydroxybutyrate) production. J. Ind. Microbiol. Biotechnol. 35: $1205-1215$

Choi M.H., Yoon S.C., Lenz R.W. (1999) Production of poly(3-hydroxybutyric acid-co4-hydroxybutyric acid) and poly(4-hydroxybutyric acid) without subsequent degradation by Hydrogenophaga pseudoflava. Appl. Environ. Microbiol. 65: 1570-1577

Doi Y., Segawa A., Kunioka M.(1990) Biosynthesis and characterization of poly(3-hydroxybutyrateco-4-hydroxybutyrate) in Alcaligenes eutrophus. Int. J. Biol. Macromol. 12: 106-111

Ermakov A.I., Arasimovich V.V., Smirnova-Ikonnikova M.I., Yarosh N.P., Lukovnikova G.A. (1972) Metody biohimicheskogo analiza rastenii [The methods of biochemical analysis of plants]. Leningrad: Kolos, 306 p. (in Russian)

Freier T. (2006) Biopolyesters in tissue engineering applications. Adv. Polym. Sci. 203: 1-61

Haywood G.W., Anderson A.J., Williams D.R., Dawes E.A., Ewing D.F. (1991) Accumulation of a poly(hydroxyalkanoate) copolymer containing primarily 3-hydroxyvalerate from simple carbohydrate substrates by Rhodococcus sp. NCIMB 40126. Int. J. Biol. Macromol. 13: 83-88

Hiramitsu M., Koyama N., Doi Y. (1993) Production of poly(3-hydroxybutyrate-co-4hydroxybutyrate) by Alcaligenes latus. Biotechnol. Lett. 15: 461-464

Hsieh W.-C., Wada Y., Chang C.-P. (2009) Fermentation, biodegradation and tensile strength of poly(3-hydroxybutyrate-co-4-hydroxybutyrate) synthesized by Delftia acidovorans. J. Taiwan Inst. Chem. E. 40: 143-147 
Kimura H., Iwama M., Sasaki S., Takeishi M. (1999) Production of polyester blend of poly(3hydroxybutyrate-co-4-hydroxybutyrate) and poly(3-hydroxyalkanoate) with saturated and unsaturated monomers from 4-hydroxybutyric acid by Chromobacterim sp. Chem. Lett. 28: 737-738

Kimura H., Ohura T., Matsumoto T., Ikarashi T. (2008) Effective biosynthesis of poly(3hydroxybutyrate-co-4-hydroxybutyrate) with high 4-hydroxybutyrate fractions by Wautersia eutropha in the presence of $\alpha$-amino acids. Polym. Int. 57: 149-157

Kunioka M., Kawaguchi Y., Doi Y. (1989) Production of biodegradable copolyesters of 3-hydroxybutyrate and 4-hydroxybutyrate by Alcaligenes eutrophus. Appl. Microbiol. Biotechnol. 30: $569-573$

LiZ.-J., ShiZ.-Y., Jian J., Guo Y.-Y., Wu Q., Chen G.-Q.(2010)Production of poly(3-hydroxybutyrateco-4-hydroxybutyrate) from unrelated carbon sources by metabolically engineered Escherichia coli. Metab. Eng. 12: 352-359

Martin D.P., Williams S.F. (2003) Medical applications of poly-4-hydroxybutyrate: a strong flexible absorbable biomaterial. Biochem. Eng. J. 16: 97-105

Mitomo H., Hsieh W.-C., Nishiwaki K., Kasuya K., Doi Y. (2001) Poly(3-hydroxybutyrate-co-4hydroxybutyrate) produced by Comamonas acidovorans. Polymer 42: 3455-3461

Nakamura S., Doi Y., Scandola M. (1992) Microbial synthesis and characterization of poly(3hydroxybutyrate-co-4-hydroxybutyrate). Macromolecules 25: 4237-4241

Park D.H., Kim B.S. (2011) Production of poly(3-hydroxybutyrate) and poly(3-hydroxybutyrateco-4-hydroxybutyrate) by Ralstonia eutropha from soybean oil. New Biotechnol. 28: 719-724.

Philip S., Keshavarz T., Roy I. (2007) Polyhydroxyalkanoates: biodegradable polymers with a range of applications. J Chem. Technol. Biotechnol. 82: 233-247

Rahayu A., Zaleha Z., .Yahya A.R.M., Majid M.I.A., Amirul A.A. (2008) Production of copolymer poly(3-hydroxybutyrate-co-4-hydroxybutyrate) through a one-step cultivation process. World J. Microbiol. Biotechnol. 24: 2403-2409

Ramachandran H., Iqbal N.M., Sipaut C.S., Abdullah A.A. (2011) Biosynthesis and characterization of poly(3-hydroxybutyrate-co-3-hydroxyvalerate-co-4-hydroxybutyrate) terpolymer with various monomer compositions by Cupriavidus sp. USMAA2-4. Appl. Biochem. Biotechnol. 164: 867-877

Rao U., Sridhar R., Sehgal P.K. (2010) Biosynthesis and biocompatibility of poly(3-hydroxybutyrateco-4-hydroxybutyrate) produced by Cupriavidus necator from spent palm oil. Biochem. Eng. J. 49: $13-20$

Renner G., Pongratz K., Braunegg G. (1996) Production of poly(3-hydroxybutyrate-co-4hydroxybutyrate) by Comamonas testosteronii. Food Technol. Biotechnol. 34: 91-95

Saito Y., Doi Y. (1994) Microbial synthesis and properties of poly(3-hydroxybutyrate-co-4hydroxybutyrate) in Comamonas acidovorans. Int. J. Biol. Macromol. 16: 99-104

Stasishina G.N., Volova T.G. (1992) Bacteria strain Alcaligenes eutrophus - the producer of protein biomass. Patent of RF, № 2053292

Tsuge T. (2002) Metabolic improvements and use of inexpensive carbon sources in microbial production of polyhydroxyalkanoates. J. Biosci. Bioeng. 94: 579-584

Vigneswari S., Vijaya S., Majid M.I.A., Sudesh K., Sipaut C.S., Azizan M.N.M., Amirul A.A. (2009) Enhanced production of poly(3-hydroxybutyrate-co-4-hydroxybutyrate) copolymer with manipulated variables and its properties. J. Ind. Microbiol. Biotechnol. 36: 547-556 
Vigneswari S., Lee A.N., Majid M.I.A., Amirul A.A. (2010) Improved production of poly(3hydroxybutyrate-co-4-hydroxybutyrate) copolymer using a combination of 1,4-butanediol and $\gamma$-butyrolactone. World J. Microbiol. Biotechnol. 26: 743-746

Volova T.G., Kalacheva G.S. (2005) The synthesis of hydroxybutyrate and hydroxyvalerate copolymers by the bacterium Ralstonia eutropha. Microbiology 74: 54-59

Volova T.G., Voinov N.A. (2004) Study of a Ralstonia eutropha culture producing polyhydroxyalkanoates on products of coal processing. Appl. Biochem. Microbiol. 40: 249-252

Volova T.G., Kalacheva G.S., Konstantinova V.M., Puzir A.P. (1992) Effect of growth conditions on polyhydroxybutyrate accumulation by hydrogen bacteria. Prikladnaya Biohimiya i Mikrobiologiya 28: 221-228 (in Russian)

Volova T.G., Mironov P.V., Vasil'yev A.D. (2006) Synthesis and study of multicomponent polyhydroxyalkanoates. Perspektivnye Materialy [Perspective Materials] 5: 35-41 (in Russian)

Volova T.G., Kalacheva G.S., Kozhevnikov I.V., Steinbüchel A. (2007) Biosynthesis of multicomponent polyhydroxyalkanoates by Wautersia eutropha. Microbiology 76: 704-711

Xie W.P., Chen G.-Q. (2008) Production and characterization of terpolyester poly(3hydroxybutyrate-co-4-hydroxybutyrate-co-3-hydroxyhexanoate) by recombinant Aeromonas hydrophila 4AK4 harboring genes phaPCJ. Biochem. Eng. J. 38: 384-389

Zhang L., Shi Z.-Y., Wu Q., Chen G.-Q. (2009) Microbial production of 4-hydroxybutyrate, poly-4hydroxybutyrate, and poly(3-hydroxybutyrate-co-4-hydroxybutyrate) by recombinant microorganisms. Appl. Microbiol. Biotechnol. 84: 909-916

\title{
Микробный синтез
}

\section{и характеристика сополимеров \\ поли(3-гидроксибутирата-со-4-гидроксибутирата)}

\author{
Н.О. Жила $a^{a, \sigma^{*}}$, Т.Г. Волова ${ }^{a, \tilde{\sigma}}$, \\ Е.Д. Николаева ${ }^{a, \tilde{\sigma}}$, Д.А. Сырвачева ${ }^{\sigma}$ \\ ${ }^{a}$ Институт биофизики \\ Сибирского отделения Российской академии наук, \\ Россия 660036, Красноярск, Академгородок \\ ${ }^{\sigma}$ Сибирский федеральный университет, \\ Россия 660041, Красноярск, пр. Свободный, 79
}

Работа посвящена перспективному представителю семейства биоразрушаемых
полигидроксиалканоатов (ПГА) сополимеру поли(3-гидрокмсибутирата-со-4гидроксибутирата) (поли(ЗГБ-со-4ГБ)). Трудности получения этого типа ПГА связаны с тем, что предщественник для синтеза мономеров 4-гидроксибутирата (4ГБ) - $\gamma$-бутиролактон токсичен для бактерий-продуцентов и при его добавлении в среду снижаются общие выходы биомассы и полимера. С использованием природных штаммов водородокисляющих бактерий Ralstonia eutropha B5786 и Cupriavidus eutrophus B10646 последний обладает повыменной 
устойчивостью $\kappa$ воздействию $\gamma$-бутиролактона, найдень условия культивирования для эффективного синтеза поли(ЗГБ/4ГБ). Получена серия высокоочищенных образиов поли(ЗГБ/4ГБ) с различным содержанием 4ГБ (от 8,7 до 24,3 мол. \%). Установлено, что включение 4ГБ в сополимер в большей степени, нежели 3-гидроксивалерат и 3-гидроксигексаноат, приводит к снижению кристалличности сополимера; получень образиы, имеющие степень кристалличности 12 и $25 \%$. Показано, что средняя молекулярная масса образиов поли(ЗГБ/4ГБ) и полидисперсность не зависят от соотношения мономеров и варьируют в широких пределах, соответственно, от 540 до 1110 кДа и от 1,91 до 2,76. Установлено, что содержание 4ГБ в исследуемом диапазоне (8,7-24,3 мол. \%) не влияло на температуру плавления сополимеров $\left(168,9-172,5^{\circ} \mathrm{C}\right)$.

Ключевые слова: водородокисляющие бактерии; поли(3-гидроксибутират-со-4гидроксибутират); $\gamma$-бутиролактон; физико-химические свойства. 